\title{
Novel biomanufacturing platform for large- scale and high-quality human T cells production
}

\author{
Jianfa Ou' ${ }^{1}$ Yingnan Si', Yawen Tang ${ }^{1}$, Grace E. Salzer ${ }^{1}$, Yun Lu', Seulhee Kim', Hongwei Qin², Lufang Zhou ${ }^{3}$ and \\ Xiaoguang $\mathrm{Liu}^{1 *}$ (D)
}

\begin{abstract}
The adoptive transfer of human T cells or genetically-engineered T cells with cancer-targeting receptors has shown tremendous promise for eradicating tumors in clinical trials. The objective of this study was to develop a novel T cell biomanufacturing platform using stirred-tank bioreactor for large-scale and high-quality cellular production. First, various factors, such as bioreactor parameters, media, supplements, stimulation, seed age, and donors, were investigated. A serum-free fed-batch bioproduction process was developed to achieve 1000-fold expansion within 8 days after first stimulation and another 500-fold expansion with second stimulation. Second, this biomanufacturing process was successfully scaled up in bioreactor with dilution factor of 10 , and the robustness and reproducibility of the process was confirmed by the inclusion of different donors' $T$ cells of various qualities. Finally, T cell quality was monitored using 12 surface markers and 3 intracellular cytokines as the critical quality assessment criteria in early, middle and late stages of cell production. In this study, a new biomanufacturing platform was created to produce reliable, reproducible, high-quality, and large-quantity (i.e. $>5$ billion) human T cells in stirred-tank bioreactor. This platform is compatible with the production systems of monoclonal antibodies, vaccines, and other therapeutic cells, which provides not only the proof-of-concept but also the ready-to-use new approach of $\mathrm{T}$ cell expansion for clinical immune therapy.
\end{abstract}

Keywords: Human T cells, Biomanufacturing platform, Stirred-tank bioreactor, Robust, High-quality and large-scale production

\section{Introduction}

Human $\mathrm{T}$ cell immunotherapies require high-quality and high-capacity cellular biomanufacturing. Current protocol for expanding tumor infiltrating $\mathrm{T}$ cells $[1,2]$ or CAR-T cells $[3,4]$ adopts the use of either traditional shaker flasks, gas-permeable GE WAVE bag [5, 6] or G-Rex bag [7]. The reported WAVE system generated 100-700 folds of $\mathrm{T}$ cell expansion from a 18-day perfusion culture [8-10], and the G-Rex system achieved up to 135-fold cell expansion from a 23-day batch culture [11].

Despite these technological advancements, the current $\mathrm{T}$ cell biomanufacturing process presents

\footnotetext{
* Correspondence: mliu@uab.edu

${ }^{1}$ Department of Biomedical Engineering, University of Alabama at Birmingham (UAB), 1670 University Blvd, Birmingham, AL 35233, USA Full list of author information is available at the end of the article
}

several weaknesses: 1) low efficiency of oxygen and nutrient transfer results in heterologous cellular metabolism, low cell viability and poor product quality; 2) ineffective process parameter control causes low bioprocess robustness; 3) lack of checkpoints in the early and middle stages of biomanufacturing for precise quality control limits the integrity and reproducibility of $\mathrm{T}$ cells for potential clinical use.

An advanced cellular biomanufacturing platform using stirred-tank bioreactor to produce high-quality and large-scale human $\mathrm{T}$ cells could overcome these technical challenges. Compared to WAVE bag, the stirred-tank bioreactor has the advantages of efficient mass transfer of oxygen and nutrients, high robustness of bioproduction, and outstanding scalability due to the precise process control of $\mathrm{pH}$, temperature, dissolved oxygen (DO), agitation, gas sparging, and 
nutrients feeding. The stirred tank has been used to produce antibodies [12], biochemicals [13], viruses, hiPSCs, hiPSC-derived cardiomyocytes, and other biologics in our lab, which consistently shows very solid and robust bioproduction capability.

The objective of this study was to develop a novel fed-batch cellular biomanufacturing process, aiming to produce $>2000 \times 10^{6}$ high-quality $\mathrm{T}$ cells with a short timeline. Various bioproduction process parameters, such as the bioreactor parameters of $\mathrm{pH}, \mathrm{DO}$, temperature, agitation and others, media, supplements, stimulation, seed age, and donors, were investigated to identify the key process regulators. The developed biomanufacturing process was also successfully scaled up in stirred-tank bioreactor. At multiple key stages of biomanufacturing, $\mathrm{T}$ cell quality was evaluated by monitoring the viable cell density, viability, T cell surface markers (total of 12) and T cell cytokines (total of 3). The accomplishments detailed in our study could significantly advance the bioproduction of human $\mathrm{T}$ cells and chimeric antigen receptor (CAR)-T cells and their application in immunotherapy.

\section{Results}

Efficient T cell biomanufacturing in stirred-tank bioreactor The overview for our biomanufacturing process is detailed in Fig. 1. Briefly, human peripheral blood mononuclear cells (PBMCs) were used to isolate $\mathrm{CD}^{+}$or $\mathrm{CD} 8^{+} \mathrm{T}$ cells with magnetic beads. The purified $\mathrm{T}$ cells were stimulated with anti-CD3 and anti-CD28 mAbs for four days to prepare the seed culture for processing in the stirred-tank bioreactor. Process parameters, such as temperature, $\mathrm{pH}$, agitation, DO, gas sparging, and cytokine supplementation, were precisely controlled. An optional second stimulation in the bioreactor extended $\mathrm{T}$ cell culture longevity and increased production capacity. The bioreactor cultures were sampled daily to monitor cell growth and quality in the early, middle and late stages of $\mathrm{T}$ cell production. In this study, the stirred-tank bioreactor-based human $\mathrm{T}$ cell biomanufacturing process was developed by evaluating multiple cell culture factors, such as basal media, medium supplements, seed culture, stimulation strategy, scale-up, and donor variability. Our optimized cell expansion timeline is also shown in Fig. 1, where human $\mathrm{T}$ cells were purified and

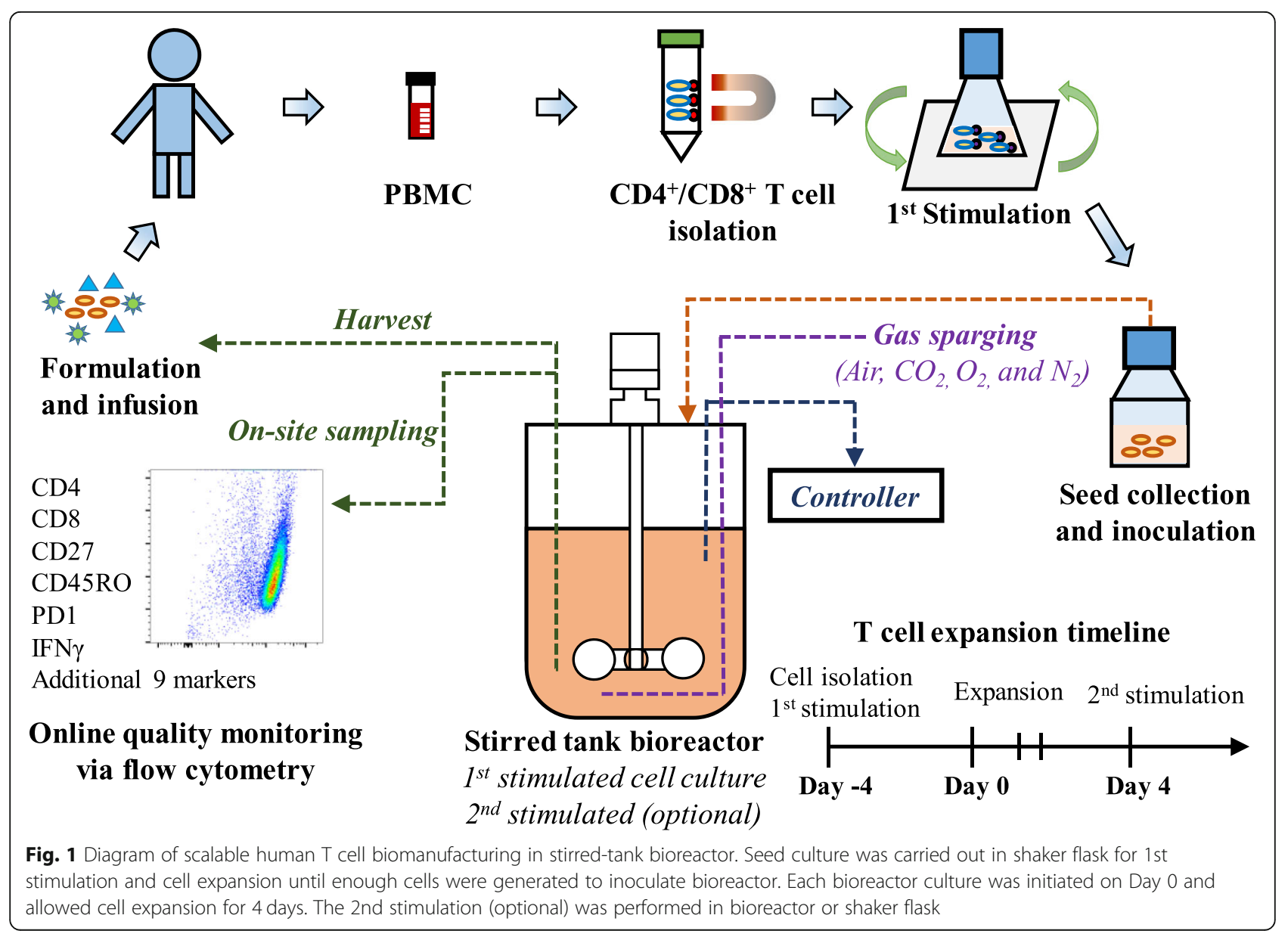


stimulated on Day - 4, expanded into growth medium with supplement on Day 0, and harvested or re-stimulated on Day 4.

\section{Basal media and supplements}

The maintenance and expansion of $\mathrm{T}$ cells is highly dependent on culture media and other factors. To reduce the risk of disease transmission and cellular product variability caused by animal derived components, three serum-free, xeno-free and animal origin-free media, i.e., AIM-V, OpTmizer and ImmunoCult, were evaluated. The seed culture was scaled up in AIM-V medium for 3 days in T75 flask after removing the stimulation magnetic beads. As shown in Fig. 2a, the maximal viable cell density (VCD) in ImmunoCult and OpTmizer media was similar $\left(2.83 \times 10^{6}\right.$ and $3.49 \times 10^{6}$ cells $/ \mathrm{mL}$ ), but higher than that in AIM-V medium $\left(1.90 \times 10^{6}\right.$ cells $\left./ \mathrm{mL}\right)$. In addition to cell growth, OpTmizer medium maintained consistent phenotype and function of $\mathrm{T}$ cells produced from the high-density cell culture (data described in following sections) and the cost of raw material was lower than the other two media, so OpTmizer was used as the basal medium throughout this study. The cytokine interleukin-2 (IL-2) is critical to a healthy $\mathrm{T}$ cell growth due to its important regulatory role in cell survival, proliferation, and differentiation $[14,15]$. The level of endogenous IL-2 is not high enough to support the high-density and rapid cell

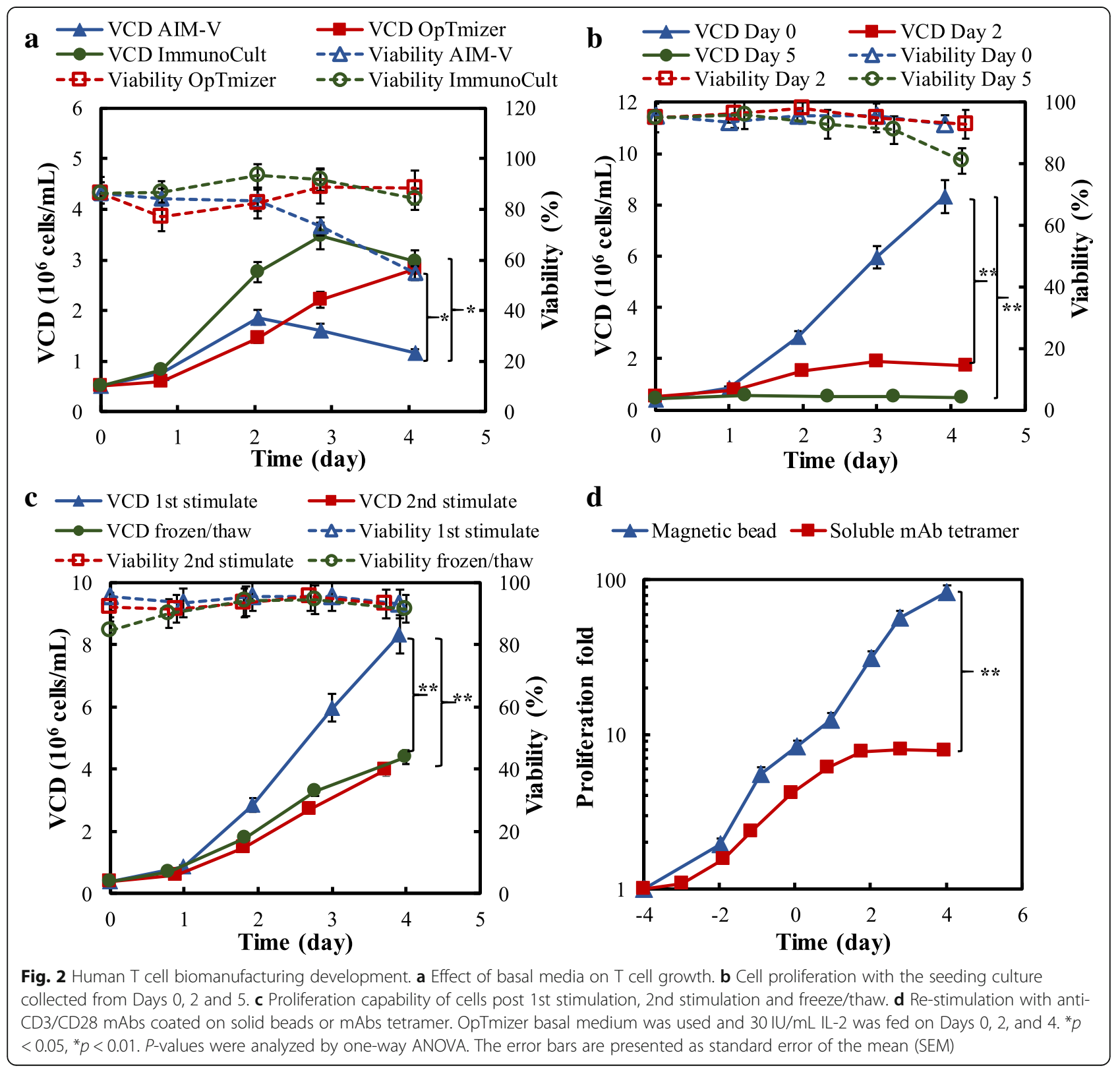


expansion rate [16], therefore basal media was supplemented with $30 \mathrm{IU} / \mathrm{mL}$ IL-2 in this study. Amino acid supplement was also evaluated in this study but had no effect on $\mathrm{T}$ cell growth (data not shown).

\section{Seed culture and stimulation}

The evaluation of seed age post 1st stimulation showed that the $\mathrm{VCD}_{\max }$ of $\mathrm{T}$ cell cultures using the seed cells collected on Days 0, 2 and 5 were 8.33, 1.89, and $0.55 \times$ $10^{6}$ cells $/ \mathrm{mL}$, respectively (Fig. $2 \mathrm{~b}$ ). Similar to in vivo T cell growth $[17,18]$, the youngest seed cells had the lowest doubling time (Td) of $13.0 \pm 0.2 \mathrm{~h}$ (Table 1). It is noted that the cells collected on Day 5 post 1st stimulation almost lost proliferative capacity, with $\mathrm{Td}$ of $99.5 \mathrm{~h}$. To extend culture longevity and $\mathrm{T}$ cell expansion capability, the effects of re-stimulation (2nd stimulation on Day 4) on cell expansion and function were evaluated. In practical application, the isolated or harvested $\mathrm{T}$ cells might need freeze for storage or transportation, so we also evaluated the effect of $\mathrm{T}$ cell freeze/thaw on cell growth. As shown in Fig. 2c, T cell proliferation post 2nd stimulation was only $50 \%$ of post 1st stimulation, with $\mathrm{VCD}_{\max }$ of 3.98 vs. $8.33 \times 10^{6}$ cells $/ \mathrm{mL}$. However, the freeze/thaw of $\mathrm{T}$ cells collected on Day 0 did not reduce cell proliferation significantly after re-stimulation, with $\mathrm{VCD}_{\max }$ of $4.38 \times 10^{6}$ cells $/ \mathrm{mL}$ (data not shown). Despite the decreased proliferation ability post re-stimulation, e.g. 500-fold after 2nd stimulation vs 1000 -fold after 1 st stimulation, serial stimulation resulted in as much as up to 500,000-fold cell expansion (Table 1).

In addition to multiple stimulations, we also tested two forms of stimulating anti-CD3 antibody and anti-CD28 antibody, including magnetic bead and soluble tetramer. Both stimulators benefited $\mathrm{T}$ cell proliferation but the mixture of two individual mAbs on beads had higher efficiency than their tetramer in liquid (Fig. $2 \mathrm{~d}$ ). Taken from the experimental results, the ideal stimulators should achieve homogenous culture with good mass transfer rate, serial stimulation in bioreactor, and robust and scalable cellular biomanufacturing. Additionally, we can improve the expansion of antigen-specific $\mathrm{T}$ cells by optimizing the ratio between anti-CD3 $\mathrm{mAb}$ and anti-CD28 mAb.

\section{Biomanufacturing scale-up and robustness}

The scale-up capability of our human T cell biomanufacturing platform was evaluated in both small and large-scale culture. Firstly, the $\mathrm{T}$ cell proliferation from cultures in 10-mLT-flask, 30-mL shaker flask and 80-mL spinner flask was compared. We found that these cultures had similar $\mathrm{VCD}_{\max }$ of $3.65-4.05 \times 10^{6}$ cells $/ \mathrm{mL}$ on Day 4 (Fig. 3a) but different viability, i.e., 52, 80 and $83 \%$ on Day 6 (data not shown). The higher viability in shaker and spinner flasks could be attributed to the higher oxygen transfer rate. Secondly, we expanded T cells in a 2-L stirred-tank bioreactor with working volume of $800 \mathrm{~mL}$ (Fig. 3b). With the automatic process control of $\mathrm{pH}, \mathrm{DO}$ and gas sparging, we produced T cells

Table 1 Summary of key parameters in human T cell biomanufacturing

\begin{tabular}{|c|c|c|c|c|c|c|c|}
\hline \multicolumn{2}{|c|}{ Biomanufacturing Parameters ${ }^{\mathrm{a}, \mathrm{b}, \mathrm{c}}$} & \multirow{2}{*}{$\frac{\text { Scale }(\mathrm{mL})}{30}$} & \multirow{2}{*}{$\frac{V C D_{\max }{ }^{d}\left(10^{6} \text { cells } / \mathrm{mL}\right)}{1.90 \pm 0.11}$} & \multirow{2}{*}{$\frac{\text { TVC }\left(10^{6} \text { cells }\right)}{56.9 \pm 3.2}$} & \multirow{2}{*}{$\frac{\text { Viability }^{d}(\%)}{76.8 \pm 2.5^{\mathrm{e}}}$} & \multirow{2}{*}{$\frac{\mu^{d}\left(h r^{-1}\right)}{0.030 \pm 0.001}$} & \multirow{2}{*}{$\frac{\mathrm{Td}^{\mathrm{c}}(\mathrm{hr})}{23.2 \pm 0.8}$} \\
\hline Medium & AIM-V & & & & & & \\
\hline & OpTmizer & 30 & $2.83 \pm 0.12$ & $84.8 \pm 3.6$ & $87.5 \pm 1.4^{\mathrm{e}}$ & $0.030 \pm 0.004$ & $23.1 \pm 2.9$ \\
\hline & ImmunoCult & 30 & $3.49 \pm 0.52$ & $104.6 \pm 15.5$ & $91.8 \pm 1.1$ & $0.041 \pm 0.000$ & $17.1 \pm 0.2$ \\
\hline \multirow[t]{4}{*}{ Seed and stimulation } & 1st stimulated Day 0 seed & 80 & $8.33 \pm 0.11$ & $666.0 \pm 8.5$ & $93.0 \pm 1.4$ & $0.053 \pm 0.001$ & $13.0 \pm 0.2$ \\
\hline & 1st stimulated Day 2 seed & 80 & $1.89 \pm 0.04$ & $151.2 \pm 3.4$ & $95.0 \pm 1.4$ & $0.029 \pm 0.002$ & $23.8 \pm 1.5$ \\
\hline & 1st stimulated Day 5 seed & 80 & $0.55 \pm 0.02$ & $44.1 \pm 2.0$ & $96.0 \pm 1.4$ & $0.007 \pm 0.001$ & $99.5 \pm 17.2$ \\
\hline & 2nd stimulated Day 0 seed & 80 & $3.98 \pm 0.06$ & $318.4 \pm 4.5$ & $93.0 \pm 0.0$ & $0.042 \pm 0.002$ & $16.7 \pm 0.7$ \\
\hline \multirow[t]{4}{*}{ Scale-up ${ }^{f}$} & $\mathrm{~T} 75$ & 10 & $4.05 \pm 0.13$ & $40.5 \pm 1.3$ & $90.5 \pm 0.7$ & $0.034 \pm 0.002$ & $20.4 \pm 0.9$ \\
\hline & SF125 & 30 & $3.65 \pm 0.18$ & $109.4 \pm 5.3$ & $91.5 \pm 2.1$ & $0.041 \pm 0.001$ & $16.9 \pm 0.4$ \\
\hline & Spinner & 80 & $3.98 \pm 0.06$ & $318.4 \pm 4.5$ & $93.0 \pm 0.0$ & $0.042 \pm 0.002$ & $16.7 \pm 0.7$ \\
\hline & Bioreactor & 800 & $6.40 \pm 0.46$ & $5120.0 \pm 367.7$ & $94.0 \pm 1.4$ & $0.046 \pm 0.002$ & $15.2 \pm 0.7$ \\
\hline
\end{tabular}

Notes

${ }^{a}$ The human T cell biomanufacturing was performed in spinner flasks for 4 days with basal medium of OpTmizer, feed of $30 \mathrm{U} / \mathrm{mL}$ IL-2 and 1 st stimulation on Day 0 and Day 2, unless otherwise specified.

${ }^{b}$ Samples from multiple donors were used in the biomanufacturing process development, and T cells isolated from the same donor were used in the evaluation of one biomanufacturing parameter (i.e., medium, seed and stimulation, and scale-up). Significant difference between bioreactor runs in triplicate with $p \leq 0.05$ was considered in the two-tailed $t$ test. The results of cross donor comparison are presented in Fig. 3.

${ }^{c}$ All data are presented as mean \pm standard error of the mean (SEM).

${ }^{\mathrm{d}}$ The variation in cell growth parameters, such as VCD, viability and cell growth rate, was caused by the different biomanufacturing process parameters.

eThe viabilities of the T cells when reaching maximal VCD are presented. The relatively low harvest viability in the medium evaluation study was caused by an extended seed culture process in the early stage of process development, i.e. 6 days instead of 4 days.

f The scale-up strategy was designed following the procedure described in Fig. 1. 

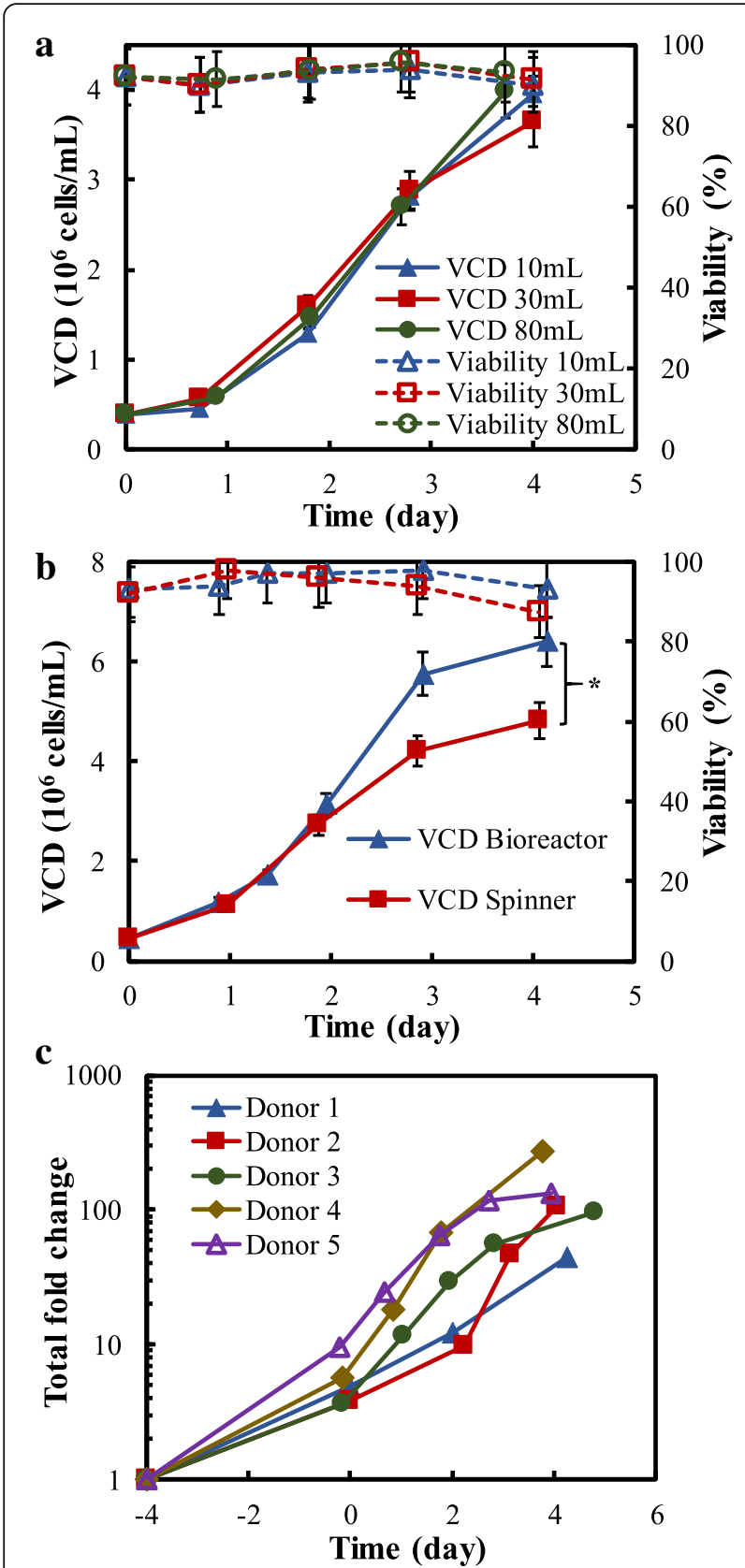

Fig. 3 Robustness and capability of the developed human T cell biomanufacturing. a Comparison of culture volume and container using the re-stimulated $\mathrm{CD}^{+} \mathrm{T}$ cell. $\mathbf{b}$ Large-scale culture in $2-\mathrm{L}$ stirred-tank bioreactor using the 1 st stimulated $\mathrm{CD} 4^{+} \mathrm{T}$ cell. $\mathbf{c}$ Total cell expansion fold was consistent among various donors. OpTmizer medium was used in the evaluation supplemented with $30 \mathrm{IU} / \mathrm{mL} \mathrm{IL}-$ 2 on Days 0,2 , and $4 .{ }^{*} p<0.05,{ }^{* *} p<0.01$. P-values were analyzed by one-way ANOVA. The error bars are presented as SEM

with $\mathrm{VCD}_{\max }$ of $6.40 \times 10^{6}$ cells $/ \mathrm{mL}$ and a high purity (av. > 95\%) of $\mathrm{CD}^{+} \mathrm{CD}^{+}$or $\mathrm{CD}^{+} \mathrm{CD}^{+} \mathrm{T}$ cells (Table 2 ). These data demonstrate that the established stirred-tank bioreactor-based biomanufacturing platform can be scaled up to produce a large amount of $\mathrm{T}$ cells.
Additionally, we tested the robustness and reproducibility of this process by cultivating $\mathrm{T}$ cells from 5 donors (Fig. 3c), and found that the total proliferation fold was in the range of 132-1011 with single stimulation. It is obvious that our new human $\mathrm{T}$ cell biomanufacturing has multiple advantages compared to traditional biomanufacturing process, including high VCD $\left(>6.0 \times 10^{6}\right.$ cells $/ \mathrm{mL}$ ), proliferation ability (>100 folds) and short production timeline (4 days).

\section{Co-culture of $\mathrm{CD}^{+}$and $\mathrm{CD}^{+} \mathrm{T}$ cells}

To understand how the interaction between $\mathrm{CD} 4^{+}$and $\mathrm{CD}^{+} \mathrm{T}$ cells affected cell proliferation in our stirred-tank bioreactor-based biomanufacturing process, we compared the cell growth of single $\mathrm{CD} 4^{+} \mathrm{T}$, single $\mathrm{CD}^{+} \mathrm{T}$, and co-cultivated $\mathrm{CD} 4^{+} \mathrm{T}$ and $\mathrm{CD}^{+} \mathrm{T}$ cells with an initial ratio of 2:1 (Fig. 4). It is found that $\mathrm{CD} 8^{+}$ $\mathrm{T}$ cells grew faster than $\mathrm{CD} 4^{+} \mathrm{T}$ cells, with the reduced $\mathrm{CD}^{+} / \mathrm{CD}^{+}$ratio from $2: 1$ on Day $0,1.5: 1$ on Day 2 and 1.5:1 on Day 4, and total $\mathrm{VCD}_{\max }$ of $4.38 \times 10^{6}$ cells $/ \mathrm{mL}$ on Day 4. Differently from co-culture, the single culture of $\mathrm{CD}_{4}^{+}$cells or $\mathrm{CD} 8^{+}$cells had similar cell growth rate from Day 0 to Day 2, and $\mathrm{CD} 4^{+}$cells continued growing while $\mathrm{CD}^{+}$stopped growing from Day 2 to Day 4. According to literature, $\mathrm{CD} 4^{+} \mathrm{T}$ cells divide rapidly and secrete cytokines to assist the initial priming and activation of the immune response of $\mathrm{CD}^{+} \mathrm{T}$ cells to antigen $[19,20]$ and improve their cytotoxicity [21, 22] when $\mathrm{T}$ helper cells are activated. In this study, we found that $\mathrm{CD}^{+} \mathrm{T}$ cells proliferated in the co-culture with $\mathrm{CD}^{+} \mathrm{T}$ helper cells had faster cell growth than single culture, which can be explained by the interaction between these two cell types. Different from $\mathrm{CD}^{+} \mathrm{T}$ cells, the cell growth rate of $\mathrm{CD}^{+} \mathrm{T}$ cells was similar in co-culture and single culture.

\section{Human $T$ cell quality assessment}

To transit from bench to bedside for cellular therapy, process validation is required to establish scientific evidence that this process is capable of consistently delivering high-quality products. It is commonly required to assure product identity, purity, safety and potency using various tests, including cell surface markers (identification), cytokine production capacity (function and potency), sterility, and absence of endotoxin, mycoplasma and viruses [23, 24]. In this study, we evaluated the surface and intracellular markers correlated with $\mathrm{T}$ cell activation, inhibition, memory, and cytokine signaling. All the surface protein analysis data indicated that the produced $\mathrm{T}$ cells were functional after expansion.

\section{$T$ cell activation signal}

As summarized in Fig. 5, effector T cells, effector memory $\mathrm{T}$ cells, and central memory $\mathrm{T}$ cells proliferated 


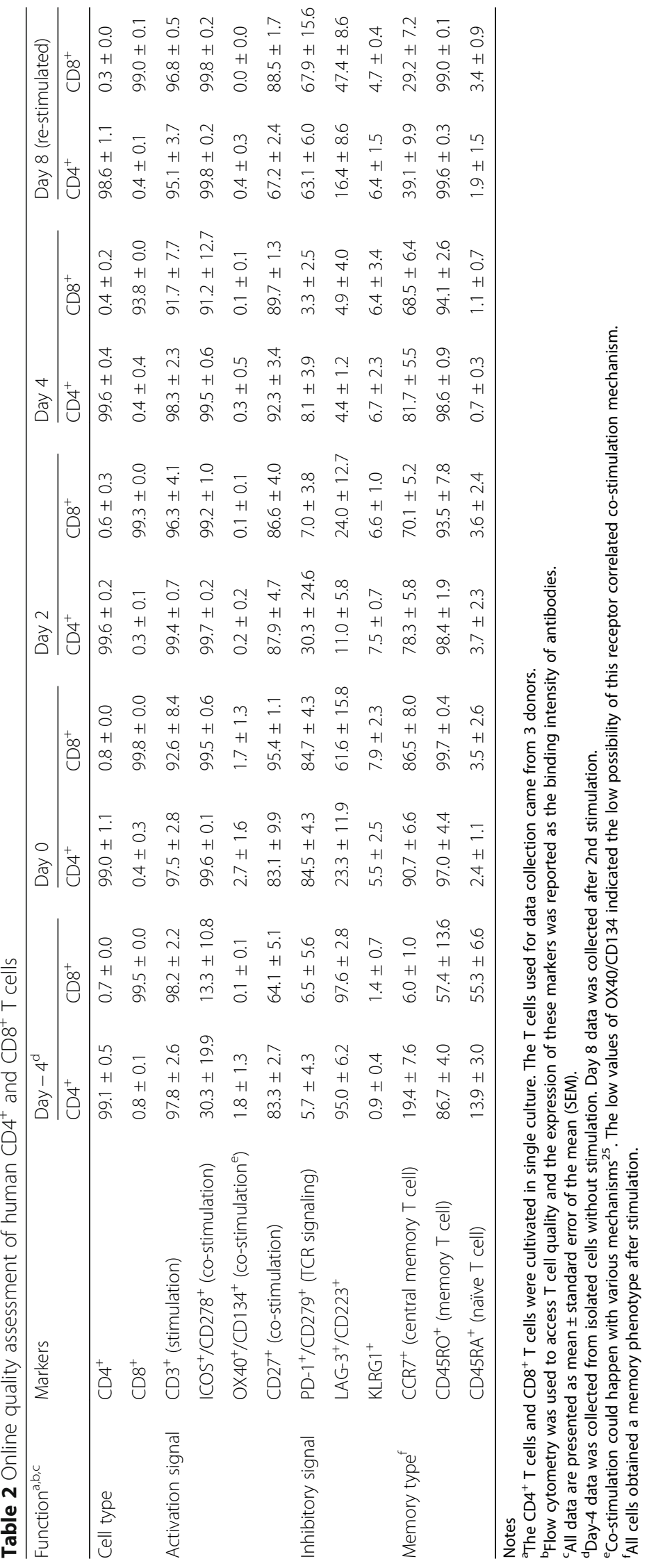



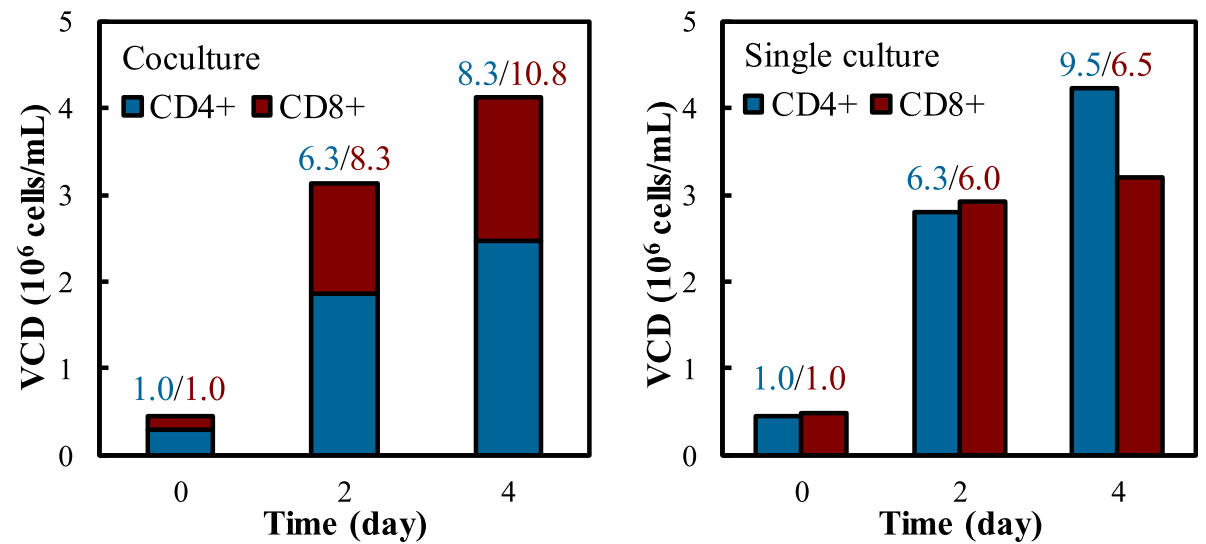

Fig. 4 Biomanufacturing of the co-culture and single culture of $\mathrm{CD}^{+}$and $\mathrm{CD} 8^{+}$cells. The $\mathrm{CD} 8^{+}$cells grew faster in the co-culture of $\mathrm{CD} 4^{+}$and $\mathrm{CD}^{+} \mathrm{T}$ cells than the single culture. The values of cell expansion fold were presented, which were calculated using the VCD of Day 0 culture as baseline. Culture conditions: 4-day seed culture with one stimulation was used; Day 0 was defined as the inoculation time of bioreactor runs; OpTmizer medium and bioreactor parameters of $37^{\circ} \mathrm{C}, \mathrm{pH} 7.4, \mathrm{DO} 70 \%$, agitation $70 \mathrm{rpm}$ and gas sparging rate $0.01 \mathrm{WM}$ were used. ${ }^{*} p<0.05$. The $p$-values were analyzed by one-way ANOVA. The error bars are presented as SEM

when instructed by the CD3/T cell receptor (TCR) and CD28 receptor. This study evaluated multiple T cell activation signaling receptors, including CD3, ICOS/CD278, OX40/CD134 and CD27. It is reported that T cells response to anti-CD3 resembles antigen activation [25], where the enzymatically cleaved antigen peptides bind to the TCR. The CD28 co-stimulation provides an essential expansion signal by promoting the survival of lymphocytes [26]. In this study, we found that the expression of CD3 was high (91.7-99.4\%) in both $\mathrm{CD}^{+}$and $\mathrm{CD} 8^{+} \mathrm{T}$ cells during the entirety of the biomanufacturing (Table 2). Additionally, $\mathrm{CD} 4^{+}$and $\mathrm{CD} 8^{+} \mathrm{T}$ cells have high purity (>99\%) after expansion (Fig. 5b). These data supported the biological evidence for the high proliferation rate of $\mathrm{T}$ cells and further indicated that our $\mathrm{T}$ cell biomanufacturing platform enables powerful cell proliferation. The expression level of the co-stimulation receptor, inducible $\mathrm{T}$ cell co-stimulatory signaling receptor (ICOS/CD278), was significantly elevated and maintained at $>99 \%$ post CD3/CD28 stimulation from 13.3-30.3\% pre-stimulation, which can improve the efficiency of immunotherapy [14]. As expected and consist with previous reports $[25,27,28]$, the expression of CD27 (64.195.4\%) had little or no change during $\mathrm{T}$ cell expansion. The $\mathrm{T}$ cells have multiple co-stimulation and co-inhibition molecular mechanisms [25]. The low expression of OX40/CD134 (0.0-2.7\%), type V family receptor, indicated the low possibility of OX40/CD134 correlated co-stimulation mechanism in the $\mathrm{T}$ cells expanded in our biomanufacturing.

\section{$T$ cell inhibition signal}

We tested the expression level of three inhibitory signaling receptors, i.e., PD-1/CD279, LAG-3/CD223, and
KLRG1 at multiple stages of the stirred-tank bioreactor cellular biomanufacturing. PD-1/CD279 is an inhibitory receptor that can prevent the $\mathrm{T}$ cells from proliferating. The upregulated expression of programmed cell death protein 1 (PD-1/CD279) on Day 0 (start point of the T cells expansion) and Day 8 (harvest time point) indicated poor proliferation ability of the cultivated $\mathrm{T}$ cells (Fig. 5 c), which may be upon TCR antigen activation or CD3 bypass [29-31] and correlate with the strength of TCR signaling [32]. The PD-1 expression increased from 5.7$6.5 \%$ on Day -4 to $84.5-84.7 \%$ on Day 0, and increased from $3.3-8.1 \%$ on Day 4 to $63.1-67.9 \%$ after 2 nd stimulation on Day 8. These data indicated that CD3/CD28 stimulation significantly up-regulated the expression of PD-1. Additionally, previous studies showed that PD-1 is also a suppressive molecule in cell cycle control [33], and its expression is low or moderate in healthy human T cells [34]. It was noted in this study that the PD-1 expression rapidly decreased to $7.0-30.3 \%$ on Day 2 and $3.3-8.1 \%$ on Day 4, indicating the suppression of PD-1. The expression of lymphocyte activation gene 3 protein (LAG-3), an inhibitory receptor involved in $\mathrm{T}$ cell exhaustion [35] and releasing suppressive signal [25], decreased from $95.0-97.6 \%$ on Day -4 to $23.3-61.6 \%$ on Day 0 and $4.4-4.9 \%$ on Day 4. The expression of killer cell lectin-like receptor subfamily G member 1 (KLRG1), a reported inhibitory signal receptor [36], was low (0.9$7.9 \%)$ during cell expansion. The overall percentage of the exhausted $\mathrm{T}$ cells $\left(\mathrm{PD}-1^{+} \mathrm{LAG}-3^{+} \mathrm{KLRG} 1^{+}\right)$was $<5 \%$ before and after cell expansion in the biomanufacturing.

\section{Memory $T$ cell/naïve $T$ cell}

Monitoring the memory cell type is very important to quality control because it could be changed by 


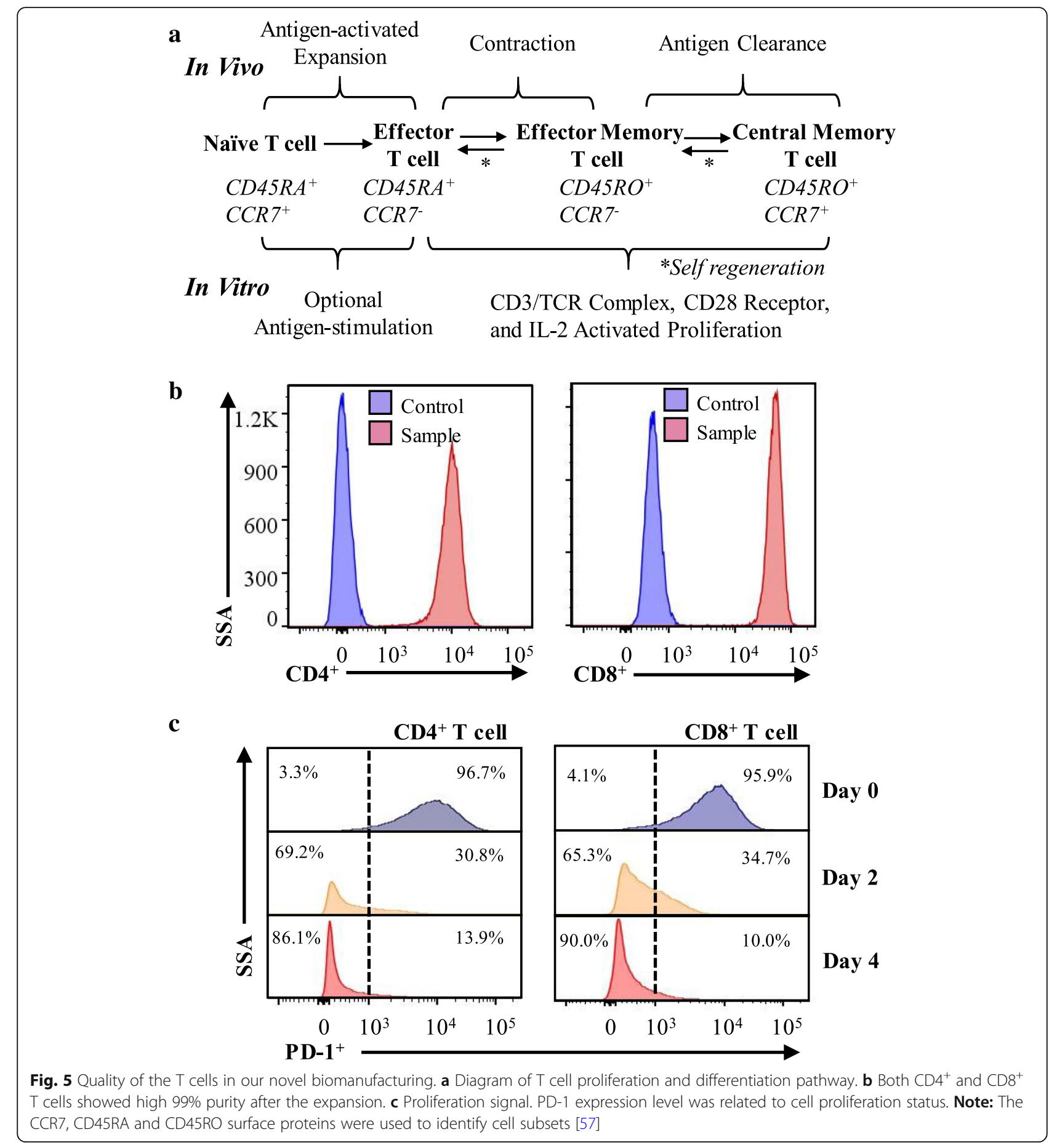

stimulation and cell expansion (Table 2). The donors' ages and health condition can also change the ratio of memory $\mathrm{T}$ cells/naïve $\mathrm{T}$ cells [37], and the central memory $\mathrm{T}$ cell can differentiate to effector memory $\mathrm{T}$ cells $[38,39]$. This study tested the expression of three memory $\mathrm{T}$ cell receptors including CCR7, CD45RO and CD45RA in $\mathrm{T}$ cells derived from same donor. As presented in Table 2, the kinetic expression profiles of these three markers were different endogenously throughout the biomanufacturing process. Specifically, CCR7 reached peak expression on Day 0 then slightly reduced from Day 0 to Day 4, suggesting that the population of central memory cells [40] was reduced during $\mathrm{T}$ cell culture. The marker CD45RO maintained high expression level during expansion, while the expression of CD45RA significantly decreased from Day -4 to Day 0 then was 
attenuated until Day 8. Elevated CD45RO expression indicated the fast cell growth of effector memory $\mathrm{T}$ cells $[41,42]$ in our stirred-tank bioreactor. The CD45RA ${ }^{+}$${ }_{\text {Low }} \mathrm{CD} 45 \mathrm{RO}^{+}{ }_{\text {High }}$ population suggested that our cultivated $\mathrm{T}$ cells adopted a memory phenotype after activation. The low cell growth of naive cell could be caused by the lack of additional antigen stimulation and cytokines (e.g., IL-4, IL-7, and IL-15) [43].

\section{Evaluation of cellular function}

We evaluated the function of $\mathrm{T}$ cells by measuring the levels of their intracellular cytokines (i.e., IFN- $\gamma$, IL-2, and (L-4) at 1st stimulation, inoculation, and harvest. The $\mathrm{CD}^{+}{ }^{+} \mathrm{T}$-helper cells were divided into T-helper type 1 (Th1) and type 2 (Th2) cells. IFN- $\gamma$ is the signature cytokine generated by Th1 to activate macrophage; IL-4 is a signature cytokine of Th2 associated with strong antibody response [44, 45]; both Th1 and Th2 can produce IL-2 [46]. The change of signature cytokine expression indicated the population of Th1 type $\mathrm{CD} 4^{+} \mathrm{T}$ helper cells decreased from Day -4 to Day 0. As shown in Table 3, the production of IFN- $\gamma$ by $\mathrm{CD}^{+} \mathrm{T}$ cells decreased by $\sim 50 \%$ from Day -4 to Day 0 then maintained low level production during expansion in bioreactor; the IL-2 level increased from Day -4 to Day 0 then maintained elevated values; and IL-4 production level was constantly low during the biomanufacturing. These data indicated that Th1 cell population was reduced post stimulation, and Th2 population had no obvious change during the cellular biomanufacturing, indicating the possible change of $\mathrm{T}$ cell function against cancer $[47,48]$. The IFN- $\gamma$ can promote $\mathrm{CD}^{+} \mathrm{T}$ cell motility and enhance the cytotoxicity against tumor and virus [49], and the memory $\mathrm{CD}^{+} \mathrm{T}$ cell is a major source of IFN- $\gamma$ [50]. Therefore, the high IFN- $\gamma$ expression in $\mathrm{CD}^{+} \mathrm{T}$ cells indicated that $\mathrm{CD}^{+}$remained cytotoxic after expansion. The high IL-2 expression in $\mathrm{CD}^{+}$
T cells can increase the antigen response [51] and induce the secretion of proinflammatory cytokines (e.g., IL-6, IL-1b, IFN- $\gamma$, and TNF- $\alpha$ ) [16] for cytotoxic function.

\section{Discussion}

In this study, we successfully developed a robust, scalable, stirred-tank bioreactor-based cellular biomanufacturing platform to generate large-quantity and high-quality human $\mathrm{CD} 4^{+}$and $\mathrm{CD} 8^{+} \mathrm{T}$ cells.

\section{New human T cell biomanufacturing}

Compared to the GE WAVE system currently used in large-scale cell culture of $\mathrm{T}$ cells or other therapeutic cells, our $\mathrm{T}$ cell biomanufacturing has several advantages. First, the perfusion culture in WAVE takes 18 days to expand by $>100$ folds from stimulation to harvest [15], [52, 53], but our stirred-tank bioreactor can achieve 100-fold expansion within 8 days. Second, the agitation and gas sparging in the stirred-tank bioreactor offered optimal oxygen transfer, nutrients transfer, and a more homogenous environment without Dynabeads. Third, our system can use a glass vessel or disposal plastic bag with the same controller that precisely controls various process parameters, which is compatible with the production systems of other therapies such as monoclonal antibodies, vaccines, and stem cells-derived therapeutic cells. This biomanufacturing platform provides not only the proof-of-concept but also the ready-to-use new approach of $\mathrm{T}$ cell expansion for clinical immune therapy. Fourth, the utilization of serum-free cell culture in our process reduces the risk of disease transmission and cellular product variability caused by animal derived component.

\section{Scalable and robust biomanufacturing}

Our T cell biomanufacturing yielded very consistent data regarding to cell growth rate, doubling time and cell

Table 3 Cytokine production by T cells expanded in stirred-tank bioreactor

\begin{tabular}{|c|c|c|c|c|c|c|c|}
\hline \multirow{2}{*}{$\begin{array}{l}\text { Data } \\
\text { source }\end{array}$} & \multirow{2}{*}{$\begin{array}{l}\text { Cytokines } \\
\text { secretion }^{a}\end{array}$} & \multicolumn{2}{|l|}{ Day -4} & \multicolumn{2}{|l|}{ Day 0} & \multicolumn{2}{|l|}{ Day 4} \\
\hline & & $\overline{\mathrm{CD}^{+}}$ & $\mathrm{CD}^{+}$ & $\overline{\mathrm{CD}^{+}}$ & $\mathrm{CD}^{+}$ & $\overline{\mathrm{CD}^{+}}$ & $\mathrm{CD}^{+}$ \\
\hline \multirow[t]{3}{*}{ This study ${ }^{b}$} & $\mathrm{IFN}-\gamma$ & $46.2-54.2$ & $50.9-62.0$ & $15.6-20.8$ & $20.3-34.8$ & $21.1-31.1$ & $39.8-50.9$ \\
\hline & IL-2 & $64.9-76.7$ & $19.8-39.5$ & 79.8-95.6 & $77.2-93.8$ & $75.7-95.9$ & $74.5-96.1$ \\
\hline & $\| \mathrm{L}-4$ & $4.6-6.5$ & $1.7-3.5$ & $4.2-8.7$ & $10.2-19.9$ & $6.0-9.1$ & $5.2-8.2$ \\
\hline \multirow[t]{3}{*}{ Literature } & IFN- $\gamma$ & $\begin{array}{l}17-23[64] \\
6.7-38.9[65]\end{array}$ & $\begin{array}{l}27-37[64] \\
20-58.4[65]\end{array}$ & N/A & & $\begin{array}{l}23-47^{b}[66] \\
15-41^{d}[67]\end{array}$ & $\begin{array}{l}42-72^{b}[66] \\
4-42[68] \\
10-41^{d}[67]\end{array}$ \\
\hline & $\mathbb{L L}-2$ & 60 [64] & $25-35$ [64] & & & $53-78^{d}[67]$ & $49-97^{d}[67]$ \\
\hline & IL-4 & $0.2-4.9[65]$ & $0.1-1.6[65]$ & & & $19-47^{c}[66]$ & $0-2^{b}[66]$ \\
\hline
\end{tabular}

Notes

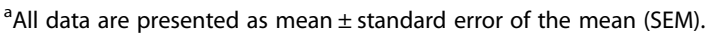

${ }^{\mathrm{b}}$ Data were collected using the T cells isolated from 3 donors.

'Data were collected from a 21-day culture.

${ }^{\mathrm{d}}$ Data were collected from a 14-day culture. 
quality at both small and large scales. Moreover, the inclusion of different donors' $\mathrm{T}$ cells in our study confirmed that our bioreactor platform can be used to expand $\mathrm{T}$ cells of various qualities. In addition, our study showed that the second stimulation further improved $\mathrm{T}$ cell expansion although the proliferation ability was reduced. However, the repeated stimulation may potentially reduce $\mathrm{T}$ cell function against infections and tumors [35], and thereby decrease their therapeutic quality. It is worthy of further investigating the effect of multiple stimulation in future studies.

\section{Stimulation strategy}

Various stimulation strategies have been previously reported for obtaining different $\mathrm{T}$-cell effector subsets. For example, IFN- $\gamma$ plus IL-12 led to Th1 cell differentiation, IL-4 helped Th2 cell development, while IL-4 plus TGF- $\beta$ resulted in Th9 cells [54]. It was reported that the central memory $\mathrm{T}$ cells showed higher anti-tumor toxicity than the effector memory $\mathrm{T}$ cells in vivo [55, 56], and the stimulation by combined anti-CD3, anti-CD28, IL-7 and IL-15 was reported to improve T cell specific cytotoxicity [57]. Refining the T cell to a specific phenotype, a.k.a. $\mathrm{T}$ cell polarization, is a cutting edge of clinical research [58], and further evaluation is needed in our new biomanufacturing platform.

\section{Online quality assessment}

In addition to the large-quantity rapid human $T$ cell expansion (i.e. $>5$ billion $\mathrm{T}$ cells within 4 days), our biomanufacturing platform used cell growth, viability, surface markers, and cytotoxic function as the critical quality assessment criteria. First, we evaluated $\mathrm{T}$ cell quality using 12 surface markers and 3 intracellular cytokines in early, middle and late stages of our biomanufacturing. Since the maintenance of cell product comparability and quality ultimately relies on the production process consistency, the multiple checkpoints for critical quality attributes could assure a high-quality therapeutic human $\mathrm{T}$ cells. It is imperative to identify potential product quality and process scale-up pain points in the early stage of $\mathrm{T}$ cell bioproduction, which has not been well established before our study. Second, it is important to harvest or re-stimulate human $\mathrm{T}$ cells before apoptosis happens. Previous studies determined the need for re-stimulation by cell size [15]. Our study indicated that we can use multiple activation signals, inhibitory signals, and cell type markers to predict the re-stimulation time point.

Application and consideration in CAR-T biomanufacturing In current clinical practice, human primary $\mathrm{T}$ cells such as tumor infiltrating $\mathrm{T}$ cells or CAR-T cells are expanded in traditional shaker flasks or gas-permeable bags. This study indicated that our novel stirred-tank bioreactor $\mathrm{T}$ cell biomanufacturing process can be applied to CAR-T cells production because our release criteria of cell viability and $\mathrm{CD}^{+}$marker are higher than the current CAR-T production in WAVE system, i.e. viability of $>$ $90 \%$ vs. $\geq 70 \%$ and $\mathrm{CD}^{+}$cells of $>90 \%$ vs. $\geq 80 \%$. Clinical trial or application reported severe in vivo cytokine storm post $T$ cell infusion [59-61], including IL-2, IL-7, IL-15, IL-12, TNF- $\alpha$, and IFN- $\gamma$ [59]. The correlation between in vitro and in vivo cytokine assessment should be investigated in order to further improve the safety of CAR-T cellular therapy.

\section{Future directions}

A stimulation without targeting specific antigen was used in this study for proof of concept. In the next step, we will use this novel platform to engineer and produce CAR-T cells that target specific cancers. Moreover, we used the defined subpopulations of $\mathrm{T}$ cells, e.g. $\mathrm{CD} 4^{+}$ and $\mathrm{CD}^{+} \mathrm{T}$ cells, to explore more details of cell quality in this study. In the future, we will compare the discovery to a leukapheresis mixture, which is currently used in CAR-T cell therapy, and guide the optimization of mixture culture cell quality. Moreover, we also plan to develop a closed cell harvest system to take the manufacturing one step closer to clinical practice [62]. Additionally, some cutting-edge technologies, such as replacing autologous $\mathrm{T}$ cells with new cell sources, will also benefit $\mathrm{T}$ cell manufacturing [63].

\section{Conclusions}

In this study, we developed a new biomanufacturing platform to produce a reliable and reproducible large quantity of human $\mathrm{T}$ cells for immune cancer therapy. The accomplishment of our study will provide not only the proof-of-concept principle but also the ready-to-use bioproduction platform for a new means of $\mathrm{T}$ cell expansion for clinical immune cancer therapy.

\section{Methods \\ Materials}

All basal media, supplements and reagents used in this study were purchased from Thermo Fisher Scientific (Waltham, MA) unless otherwise specified.

\section{T cell isolation}

Peripheral blood mononuclear cells (PBMCs) were provided by StemExpress (Folsom, CA) collecting from healthy donors under written informed consent. The PBMCs were obtained using Institutional Review Board (IRB) approved consent forms and protocols. $\mathrm{CD}^{+}$and $\mathrm{CD}^{+} \mathrm{T}$ cells were isolated using Dynabeads ${ }^{\circ} \mathrm{CD} 4$ and CD8 positive isolation kit following the manufacturing instructions, respectively. Generally, the PBMC were 
washed with buffer $1 \mathrm{CCa}^{2+}$ and $\mathrm{Mg}^{2+}$ free PBS, $0.1 \%$ BSA, 2 mM EDTA, pH 7.4) first, then incubated with magnetic beads on ice for 20 mins with gentle mixing to capture $\mathrm{CD}^{+}$and $\mathrm{CD}^{+}{ }^{+} \mathrm{T}$ cells. Held on a magnet, the supernatant was removed, and the complex of beads-cells was washed with buffer 1 twice. The $\mathrm{CD} 4^{+}$ or $\mathrm{CD}^{+} \mathrm{T}$ cells were dissociated from beads using detach reagent for 45 mins at room temperature, followed by removing magnetic beads with the magnet. The released $\mathrm{T}$ cells were washed with culture medium twice before cultivation.

\section{T cell stimulation and cell culture}

The isolated $\mathrm{CD}^{+}$and $\mathrm{CD}^{+} \mathrm{T}$ cells were seeded at $0.5 \times 10^{6} / \mathrm{mL}$ in $\mathrm{T}$ flask or shaker flask for stimulation. Two stimulations reagents were evaluated in this study: 1) Dynabeads ${ }^{\circ}$ Human T-Activator $\mathrm{CD} 3 / \mathrm{CD} 28$ beads were added to the culture at cell:bead ratio of $1: 1$ and incubated for 4 days. 2) ImmunoCult ${ }^{\text {Tw }}$ Human CD3/CD28 $\mathrm{T}$ Cell Activator (Stemcell Technologies, Vancouver, Canada) was added at $25 \mu \mathrm{L} / \mathrm{mL}$ culture. Three basal media were evaluated, including AIM-V Medium CTS, OpTmizer CTS and ImmunoCult ${ }^{\mathrm{Tw}}-\mathrm{XF} \quad \mathrm{T}$ (Stemcell Technologies). The $\mathrm{T}$ cell cultures were supplemented with $30 \mathrm{IU} / \mathrm{mL} \mathrm{IL}-2$ on Day 0 unless otherwise specified. The stirred-tank bioreactor was controlled at $37^{\circ} \mathrm{C}, \mathrm{pH}$ 7.4, DO 70\%, agitation $70 \mathrm{rpm}$ and gas sparging rate 0.01 VVM. The shaker flask culture was maintained at $37^{\circ} \mathrm{C}$, $5 \% \mathrm{CO}_{2}$ and $125 \mathrm{rpm}$, and the spinner flask culture was incubated at $37^{\circ} \mathrm{C}, 5 \% \mathrm{CO}_{2}$ and $50 \mathrm{rpm}$. The pH of all the cultures in flasks were adjusted to 7.4 once a day with $0.5 \mathrm{M} \mathrm{Na}_{2} \mathrm{CO}_{3}$. The cell expansion cultures were sampled daily to monitor cell growth by measuring the VCD and viability using Countess II automated cell counter and trypan blue (Thermo Fisher Scientific, Waltham, MA).

\section{Flow cytometry analysis}

The following antibodies used in flow cytometry analysis were purchased from BioLegend (San Diego, CA): anti-CD8a (FITC), anti-CD45RO (PerCP-Cy5.5), anti-PD-1 (PE), anti-CCR7 (PE-Cy7), anti-CD27 (APC), anti-CD4 (APC-Cy7), anti-CD45RA (BV510), anti-CD223 (PerCP-Cy5.5), anti-CD3 (PE), anti-KLRG1 (PE-Cy7), anti-CD278 (APC), anti-CD4 (APC-Cy7), anti-CD134 (BV510), anti-IFN- $\gamma$ (FITC), anti-IL-2 (PE), and anti-IL-4 (APC). The staining dyes were determined on the base of their fluorescent compatibility. Negative samples were prepared by subtracting one antibody from the panel at a time. In cell surface staining, cells were harvested and washed with staining buffer (PBS, 1\% BSA) at $400 \mathrm{~g}$ for 7 mins, and treated with Fc Receptor Blocking Solution (Biolegend $1 \mu \mathrm{L} / 1 \times 10^{6}$ cells) at $4{ }^{\circ} \mathrm{C}$ for 15 mins. Cells were then stained with antibodies and
LIVE/DEAD Blue Dead Cell Stain at $4{ }^{\circ} \mathrm{C}$ for 30 mins, washed with staining buffer twice before analysis, incubated with activation cocktail (Biolegend) for $2 \mathrm{~h}$, and mixed with monensin for $4 \mathrm{~h}$. The stained cells were harvested, washed, re-suspended in fixation solution $\left(500 \mu \mathrm{L} / 1 \times 10^{6}\right.$ cells $)$, and incubated in dark at $4{ }^{\circ} \mathrm{C}$ for 20 mins. The fixed cells were washed with Intracellular Staining Perm Wash Buffer five times, stained with anti-IFN- $\gamma$, anti-IL-2 and anti-IL-4 antibodies at $37^{\circ} \mathrm{C}$ for 30 mins, washed twice, and re-suspended in staining buffer for analysis. The LSRII flow cytometer (BD Biosciences) was used to analyze the expression of surface and intracellular markers for the $\mathrm{T}$ cell samples, and data were analyzed using FlowJo software (Tree Star). Gating was set where negative sample has $<0.5 \%$ fluorescent population.

\section{Statistical analysis}

We used the $\mathrm{T}$ cells isolated from five donors over different stages of this study and collected data from triplicate bioreactor runs. Comparisons across donors were performed by analyzing the cell function and expansion capability. All data are presented as mean \pm standard error of the mean (SEM). Two-tailed $t$ tests were used to determine the significance difference between two groups. Multiple groups were analyzed by one-way ANOVA. Statistical significance with $p$ value of $\leq 0.05$ was considered for all tests.

\section{Abbreviations \\ CAR: Chimeric antigen receptor; DO: Dissolved oxygen; IL-2: Cytokine interleukin-2; KLRG1: Killer cell lectin-like receptor subfamily G member 1; PBMC: Peripheral blood mononuclear cell; TCR: T cell receptor; Th1: T-helper type 1; Th2: T-helper type 2; VCD: Viable cell density}

\section{Acknowledgments}

This research was funded by the National Science Foundation (NSF) under Cooperative Agreement Number NSF1719625, issued by the Engineering of Biomedical Systems program. The views, opinions and/or findings expressed are those of the author(s) and should not be interpreted as representing the official views or policies of the National Science Foundation or the US Government.

\section{Funding}

NSF1719625.

\section{Availability of data and materials}

All data generated or analyzed during this study are included in this article.

\section{Authors' contributions \\ LZ and XL supervised the project. JO, YS, and SK developed the experimental protocols, implemented the stirred-tank bioreactor cellular biomanufacturing platform, and analyzed the data. JO, XL and LZ wrote the manuscript with in- put from $Y T, G S$, and $Y L$ and $H Q$. All authors read and approved the final manuscript.}

Ethics approval and consent to participate Not applicable.

Consent for publication

The manuscript is approved by all authors for publication. 


\section{Competing interests}

The authors' declare that they have no competing interests.

\section{Publisher's Note}

Springer Nature remains neutral with regard to jurisdictional claims in published maps and institutional affiliations.

\section{Author details}

'Department of Biomedical Engineering, University of Alabama at Birmingham (UAB), 1670 University Blvd, Birmingham, AL 35233, USA. ${ }^{2}$ Department of Cell, Developmental and Integrative Biology, University of Alabama at Birmingham (UAB), 1670 University Blvd, Birmingham, AL 35233 , USA. ${ }^{3}$ Department of Medicine, University of Alabama at Birmingham (UAB), Birmingham, AL 35294, USA.

Received: 26 December 2018 Accepted: 11 April 2019

Published online: 23 April 2019

\section{References}

1. Rosenberg SA, Packard BS, Aebersold PM, Solomon D, Topalian SL, Toy ST, et al. Use of tumor-infiltrating lymphocytes and Interleukin-2 in the immunotherapy of patients with metastatic melanoma. New Eng J Med. 1988:319(25):1676-80.

2. Hamanishi J, Mandai M, Iwasaki M, Okazaki T, Tanaka Y, Yamaguchi $K$, et al. Programmed cell death 1 ligand 1 and tumor-infiltrating CD8+ T lymphocytes are prognostic factors of human ovarian cancer. Proc Natl Acad Sci. 2007;104(9):3360-5.

3. Davila ML, Riviere I, Wang X, Bartido S, Park J, Curran K, et al. Efficacy and Toxicity Management of 19-28z CAR T Cell Therapy in B Cell Acute Lymphoblastic Leukemia. Sci. Trans. Med. 2014;6(224):224ra25.

4. Eyquem J, Mansilla-Soto J, Giavridis T, van der Stegen SJC, Hamieh M, Cunanan KM, et al. Targeting a CAR to the TRAC locus with CRISPR/Cas9 enhances tumour rejection. Nat. 2017:543:113.

5. Somerville RP, Devillier L, Parkhurst MR, Rosenberg SA, Dudley ME. Clinical scale rapid expansion of lymphocytes for adoptive cell transfer therapy in the WAVE(R) bioreactor. J Transl Med. 2012;10(1):69.

6. Shukla AA, Gottschalk U. Single-use disposable technologies for biopharmaceutical manufacturing. Trends Biotechnol. 2013;31(3):147-54.

7. Bajgain P, Mucharla R, Wilson J, Welch D, Anurathapan U, Liang B, et al. Optimizing the production of suspension cells using the G-Rex "M" series. Mol. Ther. Methods Clin. Dev. 2014;1:14015.

8. Hollyman D, Stefanski J, Przybylowski M, Bartido S, Borquez-Ojeda O, Taylo $C$, et al. Manufacturing validation of biologically functional T cells targeted to CD19 antigen for autologous adoptive cell therapy. J. Immunother. 2009; 32(2):169-80.

9. Levine BL. Performance-enhancing drugs: design and production of redirected chimeric antigen receptor (CAR) T cells. Cancer Gene Ther. 2015; 22(2):79-84.

10. Wang X, Riviere I. Clinical manufacturing of CAR T cells: foundation of a promising therapy. Mol Ther Oncolytics. 2016:3:16015.

11. Vera JF, Brenner LJ, Gerdemann U, Ngo MC, Sili U, Liu H, et al. Accelerated production of antigen-specific T-cells for pre-clinical and clinical applications using gas-permeable rapid expansion cultureware (G-rex). J Immunother. 2010;33(3):305

12. Ou J, Si Y, Goh K, Yasui N, Guo Y, Song J, et al. Bioprocess development of antibody-drug conjugate production for cancer treatment. PLoS One. 2018; 13(10):e0206246

13. Ou J, Xu N, Ernst P, Ma C, Bush M, Goh K, et al. Process engineering of cellulosic $n$-butanol production from corn-based biomass using Clostridium cellulovorans. Process Biochem. 2017;62:144-50.

14. Sim GC, Liu C, Wang E, Liu H, Creasy C, Dai Z, et al. IL2 Variant Circumvents ICOS+ Regulatory T-cell Expansion and Promotes NK Cell Activation. Cancer Immunol Res. 2016;4(11):983-94.

15. Levine BL, Bernstein WB, Connors M, Craighead N, Lindsten T, Thompson $C B$, et al. Effects of CD28 costimulation on long-term proliferation of CD4+ T cells in the absence of exogenous feeder cells. J. Immunol. 1997;159(12): 5921-30.

16. Siegel JP, Puri RK. Interleukin-2 toxicity. J Clin Oncol. 1991;9(4):694-704.

17. Murali-Krishna K, Altman JD. Counting antigen-specific CD8 T cells: a reevaluation of bystander activation during viral infection. Immunity. 1998; $8(2): 177-87$.
18. Butz EA, Bevan MJ. Massive expansion of antigen-specific CD8+ T cells during an acute virus infection. Immunity. 1998;8(2):167-75.

19. Janssen EM, Lemmens EE, Wolfe T, Christen U, von Herrath MG, Schoenberger SP. CD4+ T cells are required for secondary expansion and memory in CD8+ T lymphocytes. Nature. 2003;421(6925):852-6.

20. Shedlock DJ, Whitmire JK, Tan J, MacDonald AS, Ahmed R, Shen H. Role of CD4 T cell help and Costimulation in CD8 T cell responses during listeria monocytogenes infection. J Immunol. 2003;170(4):2053-63.

21. Monsurro V, Nagorsen D, Wang E, Provenzano M, Dudley ME, Rosenberg SA Marincola FM. Functional heterogeneity of vaccine-induced CD8(+) T cells. J Immunol. 2002;168(11):5933-42.

22. Woodland DL, Dutton RW. Heterogeneity of CD4(+) and CD8(+) T cells. Curr Opin Immunol. 2003:15(3):336-42.

23. Wang X, Riviere I. Manufacture of tumor- and virus-specific T lymphocytes for adoptive cell therapies. Cancer Gene Ther. 2015;22(2):85-94.

24. Lapteva N, Durett AG, Sun J, Rollins LA, Huye LL, Fang J, et al. Large-scale ex vivo expansion and characterization of natural killer cells for clinical applications. Cytotherapy. 2012;14(9):1131-43.

25. Chen L, Flies DB. Molecular mechanisms of T cell co-stimulation and coinhibition. Nat. Rev. Immunol. 2013;13(4):227-42.

26. Boise LH, Minn AJ, Noel PJ, June $\mathrm{CH}$, Accavitti MA, Lindsten T, et al. CD28 costimulation can promote $T$ cell survival by enhancing the expression of Bcl-xL. Immunity. 1995;3(1):87-98.

27. Croft M. The role of TNF superfamily members in T-cell function and diseases. Nat Rev Immunol. 2009;9(4):271-85.

28. Shen CJ, Yang YX, Han EQ, Cao N, Wang YF, Wang Y, Zhao YY, Zhao LM, Cu J, Gupta P, Wong AJ, Han SY, et al. Chimeric antigen receptor containing ICOS signaling domain mediates specific and efficient antitumor effect of T cells against EGFRvIII expressing glioma. J. Hematol. Oncol. 2013;6(1):33.

29. Honda T, Egen JG, Lammermann T, Kastenmuller W, Torabi-Parizi P, Germain $\mathrm{RN}$. Tuning of antigen sensitivity by $\mathrm{T}$ cell receptor-dependent negative feedback controls T cell effector function in inflamed tissues. Immunity. 2014;40(2):235-47

30. Okazaki T, Chikuma S, Iwai Y, Fagarasan S, Honjo T. A rheostat for immune responses: the unique properties of PD-1 and their advantages for clinical application. Nat. Immunol. 2013;14(12):1212-8.

31. Chikuma S, Terawaki S, Hayashi T, Nabeshima R, Yoshida T, Shibayama S, et al. PD-1-mediated suppression of IL-2 production induces CD8+ T cell anergy in vivo. J Immunol. 2009;182(11):6682-9.

32. Simon S, Labarriere N. PD-1 expression on tumor-specific T cells: friend or foe for immunotherapy? Oncoimmunol. 2017;7(1):e1364828.

33. Patsoukis N, Sari D, Boussiotis VA. PD-1 inhibits T cell proliferation by upregulating p27 and p15 and suppressing Cdc25A. Cell Cycle. 2012;11(23):4305-9.

34. Duraiswamy J, Ibegbu CC, Masopust D, Miller JD, Araki K, Doho GH, et al. Phenotype, function, and gene expression profiles of programmed death1(hi) CD8 T cells in healthy human adults. J. Immunol. 2011;186(7):4200-12.

35. Wherry EJ, Kurachi M. Molecular and cellular insights into T cell exhaustion. Nat. Rev. Immunol. 2015;15(8):486-99

36. Henson SM, Akbar AN. KLRG1--more than a marker for T cell senescence. Age (Dordr). 2009;31(4):285-91.

37. Hodes RJ. Aging and the immune system. Immunol Rev. 1997;160:5-8

38. Yim CY, Jr JBH, McGregor JR, Galinsky RE, Samlowski WE. Use of N-acetyl cysteine to increase intracellular glutathione during the induction of antitumor responses by IL-2. J Immunol. 1994;152(12):5796-805.

39. Roederer M, Staal FJ, Raju PA, Ela SW, Herzenberg LA, Herzenberg LA. Cytokine-stimulated human immunodeficiency virus replication is inhibited by N-acetyl-L-cysteine. Proc Natl Acad Sci. 1990;87(12):4884-8.

40. Sallusto F, Langenkamp A, Geginat J, Lanzavecchia A. Functional subsets of memory $T$ cells identified by CCR7 expression. Lymphoid Organogenesis: Springer; 2000. p. 167-71.

41. Kaech SM, Cui W. Transcriptional control of effector and memory CD8+ T cell differentiation. Nat. Rev. Immunol. 2012;12(11):749-61.

42. Masopust $D$, Schenkel JM. The integration of T cell migration, differentiation and function. Nat. Rev. Immunol. 2013:13(5):309-20.

43. Sprent J. Burnet oration. T-cell survival and the role of cytokines. Immunol. Cell. Biol. 2001;79(3):199-206.

44. Mosmann TR, Coffman RL. TH1 and TH2 cells: different patterns of lymphokine secretion lead to different functional properties. Annu. Rev. Immunol. 1989;7:145-73.

45. Mosmann TR, Li L, Sad S. Functions of CD8 T-cell subsets secreting different cytokine patterns. Semin. Immunol. 1997;9(2):87-92. 
46. Zhu J, Yamane H, Paul WE. Differentiation of effector CD4 T cell populations (*). Annu. Rev. Immunol. 2010;28:445-89.

47. Trinchieri G. Interleukin-12: a cytokine produced by antigen-presenting cells with immunoregulatory functions in the generation of T-helper cells type 1 and cytotoxic lymphocytes. Blood. 1994;84(12):4008-27.

48. Knutson KL, Disis ML. Tumor antigen-specific T helper cells in cancer immunity and immunotherapy. Cancer Immunol. Immunother. 2005;54(8): 721-8.

49. Bhat $\mathrm{P}$, Leggatt $\mathrm{G}$, Waterhouse $\mathrm{N}$, Frazer $\mathrm{IH}$. Interferon-gamma derived from cytotoxic lymphocytes directly enhances their motility and cytotoxicity. Cell Death. Dis. 2017;8(6):e2836

50. Kambayashi $T$, Assarsson E, Lukacher AE, Ljunggren HG, Jensen PE. Memory CD8+ T cells provide an early source of IFN-gamma. J. Immunol. 2003; 170(5):2399-408.

51. Pearce EJ, Caspar P, Grzych JM, Lewis FA, Sher A. Downregulation of Th1 cytokine production accompanies induction of Th2 responses by a parasitic helminth, Schistosoma mansoni. J. Exp. Med. 1991;173(1):159-66.

52. Singh $\mathrm{H}$, Moyes JS, Huls MH, Cooper LJ. Manufacture of T cells using the Sleeping Beauty system to enforce expression of a CD19-specific chimeric antigen receptor. Cancer Gene Ther. 2015;22(2):95-100.

53. Kaiser AD, Assenmacher M, Schroder B, Meyer M, Orentas R, Bethke U, et al. Towards a commercial process for the manufacture of genetically modified T cells for therapy. Cancer Gene Ther. 2015;22(2):72-8.

54. Coghill JM, Sarantopoulos S, Moran TP, Murphy WJ, Blazar BR, Serody JS. Effector CD4+ T cells, the cytokines they generate, and GVHD: something old and something new. Blood. 2011;117(12):3268-76.

55. Klebanoff CA, Gattinoni L, Torabi-Parizi P, Kerstann K, Cardones AR, Finkelstein SE, et al. Central memory self/tumor-reactive CD8+ T cells confer superior antitumor immunity compared with effector memory $T$ cells. Proc. Natl. Acad. Sci. U S A. 2005;102(27):9571-6.

56. Barber DL, Wherry EJ, Ahmed R. Cutting edge: rapid in vivo killing by memory CD8 T cells. J. Immunol. 2003:171(1):27-31.

57. Gargett T, Brown MP. Different cytokine and stimulation conditions influence the expansion and immune phenotype of third-generation chimeric antigen receptor T cells specific for tumor antigen GD2. Cytother. 2015;17(4):487-95.

58. Levine BL, Miskin J, Wonnacott K, Keir C. Global manufacturing of CAR T cell therapy. Mol Ther Methods Clin Dev. 2017:4:92-101.

59. Brentjens R, Yeh R, Bernal Y, Riviere I, Sadelain M. Treatment of chronic lymphocytic leukemia with genetically targeted autologous T cells: case report of an unforeseen adverse event in a phase I clinical trial. Mol Ther. 2010;18(4):666-8.

60. Morgan RA, Yang JC, Kitano M, Dudley ME, Laurencot CM, Rosenberg SA. Case report of a serious adverse event following the administration of $T$ cells transduced with a chimeric antigen receptor recognizing ERBB2. Mol Ther. 2010;18(4):843-51.

61. Porter DL, Levine BL, Kalos M, Bagg A, June CH. Chimeric antigen receptormodified T cells in chronic lymphoid leukemia. N Engl J Med. 2011;365(8): 725-33

62. Donia M, Larsen SM, Met O, Svane IM. Simplified protocol for clinical-grade tumor-infiltrating lymphocyte manufacturing with use of the Wave bioreactor. Cytother. 2014;16(8):1117-20.

63. Themeli M, Riviere I, Sadelain M. New cell sources for T cell engineering and adoptive immunotherapy. Cell Stem Cell. 2015;16(4):357-66.

64. Morvan PY, Picot C, Dejour R, Genetet B, Genetet N. Distinct pattern of IL-2 and IFN-gamma gene expression in CD4 and CD8 T cells: cytofluorometric analysis at a single cell level using non-radioactive probes. Cell Mol Biol. 1995;41(7):945-57.

65. Nakamura K, Amakawa R, Takebayashi M, Son Y, Miyaji M, Tajima K, et al. IL4-producing CD8(+) T cells may be an immunological hallmark of chronic GVHD. Bone Marrow Transplant. 2005;36(7):639-47.

66. Lam BS, Kokaji A, Szilvassy SJ, Thomas TE, Eaves AC, FRCPC, Wognum AW. Rapid expansion of functional human $T$ cells using a novel serum-free and xeno-free culture medium. Vancouver: CCIC 2015; 2015.

67. Smith C, Okern G, Rehan S, Beagley L, Lee SK, Aarvak T, et al. Ex vivo expansion of human $T$ cells for adoptive immunotherapy using the novel Xeno-free CTS immune cell serum replacement. Clin Transl Immunol. 2015 4(1):e31.

68. Biller H. Interferon-g secretion of peripheral blood CD81 T lymphocytes in patients with bronchial asthma: In vitro stimulus determines cytokine production. 2001. PubMed PMID: 11703361.

Ready to submit your research? Choose BMC and benefit from:

- fast, convenient online submission

- thorough peer review by experienced researchers in your field

- rapid publication on acceptance

- support for research data, including large and complex data types

- gold Open Access which fosters wider collaboration and increased citations

- maximum visibility for your research: over $100 \mathrm{M}$ website views per year

At $\mathrm{BMC}$, research is always in progress.

Learn more biomedcentral.com/submissions 